\title{
Fordypning, frihet og fravær av stress Erfaringer med estetiske uttrykksformer i teoretiske fag på ungdomstrinnet
}

\begin{abstract}
Sammendrag
Et gjennomgående prinsipp i de norske læreplanene for grunnskolen er at elevene skal lære og utvikle seg gjennom estetiske uttrykksformer, som for eksempel rollespill, tegning og bevegelse, i alle fag. Imidlertid synes både estetiske fag og estetisk opplevelse og utfoldelse i andre fag å være marginalisert i dagens utbytteorienterte utdanningspolitikk, og mange lærerstudenter velger bort estetiske fag fra sin utdanning. Mot dette bakteppet er forskningsspørsmålet for denne undersøkelsen: Hvordan kan estetiske uttrykksformer være fruktbare for undervisningen i teoretiske fag på ungdomstrinnet?

I denne undersøkelsen er læreres og elevers erfaringer og opplevelser belyst gjennom tre strategisk utvalgte caser i henholdsvis fagene samfunnsfag, matematikk og norsk. Datamaterialet består av observasjonsnotater, filmer og kvalitative intervju med tre lærere og 28 elever. Ved induktiv tematisk analyse av hele datamaterialet ble fravær av stress identifisert som et overordnet tema. Det overordnede temaet er konstituert av to undertema; overskridelse og selvbestemmelse, som hvert på sin måte bidrar til å nyansere det overordnede temaet.

Resultatene er i tråd med tidligere forskning på estetiske uttrykksformer i utdanning, og synliggjør hvordan estetisk opplevelse og utfoldelse kan relateres til fravær av stress i teoretiske fag på ungdomstrinnet, noe som kan ha betydning for elevenes helhetlige utvikling og danning i en resultatorientert skole.
\end{abstract}

Nøkkelord: estetiske uttrykksformer; teoretiske fag; fravær av stress; danning

\section{Immersion, Freedom and Low Stress Experience Aesthetic Expressions in Academic Subjects in Lower Secondary School}

\begin{abstract}
A general principle in the Norwegian curriculum is that students are to learn and develop through aesthetic expressions, such as role playing, drawing or music, in all subjects. However, aesthetic elements; both aesthetic subjects and aesthetic expressions in other subjects, seem marginalized in today's outcome-based education policy, and the number of teachers with aesthetic competence is gradually being reduced. Based on this, the
\end{abstract}


research question of this study is: How may aesthetic expressions be beneficial when teaching academic subjects in lower secondary school?

In this investigation, teachers' and students' experiences are highlighted through three strategically selected cases in the subjects Social Science, Mathematics and Norwegian respectively. The data material consists of observation notes, films, and qualitative interviews with three teachers and 28 pupils. By using an inductive thematic analysis, low stress experience stress was identified as an overarching theme, constituted by two sub-themes that were identified as transcendence and selfdetermination, which each add different qualities to the overarching theme.

The results align with existing research on aesthetic elements in education and contribute to nuanced understandings within the field by showing how aesthetic activity may relate to low stress experiences in academic subjects, something that could have an impact on the pupils' holistic development in a result-oriented school.

Keywords: aesthetic expressions; academic subjects; low stress; Bildung

\section{Innledning}

$\AA$ styrke det estetiske elementet i utdanningen anbefales fra forskningshold både nasjonalt og internasjonalt (Bamford, 2008; Chemi, 2010; Eriksson, Heggstad, Heggstad \& Cziboly, 2014; Lindstrand \& Selander, 2009; Stevenson \& Deasy, 2005; Østern, Selander \& Østern, 2019). Anbefalingen gjelder en styrking av de estetiske fagene i seg selv, samt å integrere estetiske uttrykksformer også i andre fag enn de praktiske og estetiske fagene. Det samme finner man også igjen i flere av den norske skolens styringsdokumenter (Meld. St. 22 (2010-2011); Meld. St. 28 (2015-2016)). I overordnet del i gjeldende læreplan slås det fast at lærere skal legge til rette for estetiske uttrykksformer i alle fag: «Elevene skal lære og utvikle seg gjennom sansning og tenkning, estetiske uttrykksformer og praktiske aktiviteter» (Kunnskapsdepartementet, 2020, s. 11).

Estetiske uttrykksformer i andre fag, som er utgangspunktet for min studie, kan være rollespill, å utforske et emne gjennom kunst, lage en film, tegne eller uttrykke seg gjennom lyd og bevegelse (Utdanningsdirektoratet, 2020). Uavhengig av hvilket fag det undervises i, hevdes det i forskning at estetiske uttrykksformer er av vesentlig betydning blant annet for å skape interesse for undervisningen, og for utvikling av selvstendighet og kritisk tenkning (Brekke \& Willbergh, 2017; Sæbø, 2009, 2010; Ulvik, 2020; Østern et al., 2019). Å skape engasjement og interesse for undervisningen synes å ha betydning blant annet for å redusere elevenes opplevelse av stress i skolehverdagen (Lillejord, 2017).

Fravær av stress, i betydningen negativt stress (Lillejord, 2017) er denne undersøkelsens mest fremtredende trekk. Resultatene viser at når elevene engasjeres i estetisk aktivitet i teoretiske fag, kan de fordypes i virksomheten slik at tid og sted overskrides (Gadamer, 2010), og det flertydige ved estetisk symbolsk form (Drotner, 1991) kan skape rom for elevenes frihet til selvbestemmelse, slik at utfordringer fremstår som håndterbare. 
Imidlertid står estetiske uttrykksformer i andre fag i fare for å bli fortrengt av resultatmål, som er mer opplagte, lettere konkretiserbare og målbare, og utbyttet av undervisningen ser ut til å tillegges mer verdi enn prosessene elevene deltar i (Bamford, 2012; Brekke \& Willbergh, 2017; Hohr, 2015; Prøitz \& Nordin, 2019). Forskning fra klasseromspraksis kan tyde på at estetiske uttrykksformer i liten grad er ivaretatt i andre fag på ungdomstrinn og videregående trinn (Hodgson, Rønning \& Tomlinson, 2012; Klette, 2003, 2020; Kvam \& Ulvik, 2019; Sæbø, 2010; Ulvik, 2020). Estetiske uttrykksformer synes i tillegg å være lite systematisk integrert i grunnskolelærerutdanningene, og det etterlyses derfor mer forskning på betydningen av estetiske uttrykksformer både i lærerutdanningene og i grunnopplæringen (By et al., 2020).

Med denne studien ønsker jeg derfor å bidra til forskningsfeltet ved å undersøke betydningen av estetiske uttrykksformer i andre fag enn de praktiske og estetiske fagene på ungdomstrinnet. Andre fag forstås som teoretiske fag. Begrepet teoretiske fag er hentet fra læreplandiskursen (Haug, 2003, s. 88; Telhaug, 2004, s. 98), og består i denne undersøkelsen av fagene samfunnsfag, matematikk og norsk. Teoretiske fag som begrep anvendes for å skille disse fagene fra praktiske fag som kroppsøving og mat og helse, samt estetiske fag som musikk og kunst og håndverk (Meld. St. 22 (2010-2011), s. 38).

Følgende forskningsspørsmål er utgangspunktet for denne studien: Hvordan kan estetiske uttrykksformer vœre fruktbare for undervisningen i teoretiske fag på ungdomstrinnet?

Forskningsspørsmålet belyses ved å undersøke læreres og elevers erfaringer og opplevelser med estetiske uttrykksformer i samfunnsfag, matematikk og norsk i 9. og 10. klasse, og bygger på tre strategisk utvalgte caser i de respektive fagene. Ved å undersøke tre fag gjennom tre caser, ønsker jeg å løfte frem det allmenndidaktiske perspektivet, fremfor det fagspesifikke. Datamaterialet består av film, observasjonsnotater, semistrukturerte dybdeintervju med tre lærere og gruppeintervju samt individuelle intervju med til sammen 28 elever.

Teoretisk tas det utgangspunkt i Klafki (2000), Gadamer (2010) og Deweys (1934/2008) perspektiver på estetikk i lys av danningsteoretisk allmenndidaktikk (Willbergh, 2019). Ved induktiv tematisk analyse (Braun \& Clarke, 2006) av hele datamaterialet, ble fravær av stress identifisert som et overordnet tema. Fravær av stress belyses ut fra to undertema, som er kategorisert som overskridelse og selvbestemmelse. Undertemaene bidrar på ulike vis til å nyansere hovedtemaet, men handler på et overordnet nivå om det samme.

I det følgende vil det teoretiske rammeverket for studien redegjøres nærmere for. Deretter følger en beskrivelse av de tre casene, før de metodologiske overveielsene skildres. Resultatene fra undersøkelsen vil så presenteres, før disse avslutningsvis diskuteres i lys av den nåtidige skolekonteksten i Norge. 


\section{Teori}

Det estetiske, i betydningen det sansemessige (Malmanger, 2000), kan betraktes som en immanent del av all undervisning og læring, der kroppslige, kognitive og emosjonelle erfaringer er komplekst forbundet og sammenfiltret i hverandre (Lewis, 2012; Østern et al., 2019). I denne undersøkelsen er det estetiske ikke forbeholdt de estetiske fagene, men betraktes som grunnleggende for pedagogikken i form av at alle fag har innslag av følelse, intuisjon og fortolkning (Løvlie, 1990). Estetiske uttrykksformer forstås i denne artikkelen i bred forstand, og dreier seg om aktivt arbeid med sanselige opplevelser og formskapende aktiviteter (Østern et al., 2019).

Formen avgrenser estetisk aktivitet fra det rent sansemessige, fordi formen er tilsiktet og medierer erfaringer. Formelementet viser til at det er en viss regelmessighet til stede i selve formen, og står som sådan motsetning til det kaotiske og tilfeldige (Hohr, 2015; Østern, 2010). Formen kan i så måte være betydningsfull for at en erfaring skal kunne oppleves som en estetisk erfaring (Dewey, 1934/2008). Estetiske erfaringer skiller seg fra formålsløse erfaringer ved at delene i erfaringen har en indre sammenheng, og når en fullbyrdelse. Den estetiske erfaringen kan da gi en emosjonell kvalitet som føles umiddelbart når erfaringen fullendes (Dewey, 1938/1974).

Det skapende elementet ved estetisk symbolsk form kan gjøre arbeidet mer personlig for elevene ved at det de skaper ikke bare er en avbildning av noe som finnes, men et uttrykk for hvordan man har forstått noe (Lindstrand \& Selander, 2009). Estetisk symbolsk form rommer også muligheter for tolkning og flertydighet (Drotner, 1991), og den enkeltes erfaringsbakgrunn kan spille inn i tolkningen, noe som gir mulighet for å knytte lærestoffet til elevenes ulike interessefelt (Dewey, 1902/1964).

I skolens styringsdokumenter fremheves opplevelse og skapende virksomhet som vesentlige erfaringer knyttet til skolens danningsoppdrag (Kunnskapsdepartementet, 2019, 2020; Meld. St. 28 (2015-2016)), i tråd med et syn på kunst og estetisk virksomhet som en integrert del av alle menneskers danning, læring, kultur og hverdagsliv (Austring \& Sørensen, 2019; Dewey, 1934, 1997).

I den klassiske kontinentale danningstradisjonen, som norsk skole har vært influert av (Biesta, 2020; Hilt, Riese \& Søreide, 2019; Prøitz \& Nordin, 2019), betraktes estetisk aktivitet som en del av allmenndanningen. Kreativ egenaktivitet og estetisk opplevelse og utfoldelse relateres til frihet og selvbestemmelse, som er sentralt blant annet for å utvikle autonomi. Estetisk aktivitet knyttes i tillegg til menneskets kultivering av sensitivitet, opplevelsen av sammenheng med natur og andre mennesker, utvikling av fantasi, evne til å leke og til å sosialiseres (Klafki, 2000). Utvikling av hele mennesket står sentralt, og å utvikle en estetisk sans anses som like viktig som utvikling av kognitive ferdigheter og sosial kompetanse 
(Pestalozzi, 1894). Estetisk virksomhet og kreativ aktivitet kan slik betraktes som essensielt for menneskets helhetlige utvikling.

Gadamer (2010) betrakter lek som en essensiell værensmåte innenfor det estetiske området. Leken har sitt eget vesen, uavhengig at de lekendes bevissthet. Lekens subjekt er ikke den som leker, men selve leken. Leken blir subjektet på den måten at den som leker blir trollbundet av selve leken, og slik «holder [leken] ham i spill» (s. 137). Lekens tiltrekning og fascinasjon ligger i risikoen for at det kanskje «ikke går» eller at man ikke får det til. Leken har et overskridende eller transcenderende element på den måten at den som leker kan oppslukes av det som skjer på en så intens måte at man blir hengitt til selve leken, løsrevet fra tid og rom; en indre tilstand der man er så konsentrert om aktiviteten at tiden glemmes og selvbevisstheten forsvinner.

$\AA$ vektlegge det aktivt-sanselige og emosjonelle gjennom estetisk opplevelse og utfoldelse kan lede til opplevelsesintensitet (Næss, 1976) fordi indre verdier som følelser, kreativitet og fantasi får rom i undervisningen (Næss, 1999). Estetisk opplevelse og utfoldelse kan skape et samspill mellom kroppslige, kognitive og emosjonelle erfaringer i undervisningen, i tråd med et helhetlig perspektiv på utdanning.

\section{Beskrivelse av casene}

I det følgende gis en nærmere beskrivelse av hver av de tre prosjektene som er grunnlaget for den empiriske undersøkelsen. Hvert prosjekt involverte henholdsvis 53 deltakende elever - til sammen 159 elever.

\section{Samfunnsfag}

Våren 2020 fulgte jeg et prosjekt i samfunnsfag på 9. trinn i to uker. Ved oppstart av perioden om temaet 1 . verdenskrig, introduserte lærer stasjonsarbeid i grupper, kalt Kunst under krigen. Lærer hadde valgt ut tre billedkunstverk (Egon Schiele: Løytnant Heinrich Wagner, Otto Dix: Skull, Christopher Nevinson: French Troops Resting), to dikt (Herbert Read: The Happy Warrior, Wilfred Gibson: Back) og to musikkvideoer (George M. Cohan: Over There, Paul McCartney: Pipes of Peace). Det var refleksjonsspørsmål til hver stasjon, og gruppene rullerte, slik at alle fikk oppleve de ulike kunstuttrykkene. I denne delen av prosjektet innebar det estetiske elementet at elevene fikk direkte, sanselige og intuitive erfaringer av 1 . verdenskrig gjennom kunstformene bilder, dikt og musikk.

I tillegg skulle elevene, individuelt eller i gruppe, lage et estetisk uttrykk, som skulle uttrykke en sammenheng med 1 . verdenskrig. Her sto de fritt til å velge både hva de skulle lage og hvordan de ville lage det. Det estetiske elementet i denne delen av prosjektet besto i at elevene skulle fordype seg i en skapende prosess, der de skulle omforme sine inntrykk av 1 . verdenskrig til estetiske 
formuttrykk, som i dette tilfellet var å modellere og forme i ulike materialer, skrive dikt, tegne, lage film, collage og musikk.

\section{Matematikk}

Våren 2020 fulgte jeg et prosjekt i matematikk på 9. trinn, som var en introduksjon til emnet geometri. I dette prosjektet fikk elevene i oppgave å utvikle et mønster ved å anvende tesseleringsteknikk. Lærer introduserte temaet med å vise elevene bilder av enkle og mer kompliserte mønster fra slottet Alhambra i Granada, Spania, og deretter skulle elevene utvikle sine egne mønstre ut fra noen prinsipper som lærer hadde gjennomgått. Da elevene hadde skapt mønsteret, skulle de fylle hele flaten med figurene uten at disse overlappet, og dette skulle til slutt fargelegges. Elevene kunne velge om de ønsket A-4 eller A-3-ark som flate.

Det estetiske elementet var i denne oppgaven todelt. Det ene var opplevelsen av utsmykningen av slottet i Alhambra. Ut fra bildene av de ulike mønstrene, ble det også diskutert hvilke matematiske egenskaper ved de flatedekkende mønstrene som gjorde disse interessante og vakre. Slik ble opplevelsene av utsmykningen av slottet et grunnlag for matematiske samtaler der både faglige og estetiske elementer ble satt i spill. I tillegg besto det estetiske elementet i at elevene skulle skape sine egne formuttrykk, og slik bearbeide inntrykkene ved å uttrykke sine egne erfaringer av mønstrene.

\section{Norsk}

Høsten 2020 fulgte jeg et prosjekt i norsk på 10. trinn i to uker. Temaet var dramasjangeren, og lærer introduserte Ibsens skuespill Peer Gynt ved å delvis fortelle handlingen og delvis avspille lydbokklipp fra stykket. Parallelt med at elevene lyttet, skulle de illustrere handlingen gjennom å tegne det de festet seg ved. Det estetiske elementet i denne delen av prosjektet, var at elevene skulle omforme sine inntrykk av stykket til egne uttrykk.

Etter å ha fått innblikk i stykkets handling, karakterer og tema som helhet, fikk elevene utdelt en skriftlig versjon av Bukkerittet fra stykket. Gruppevis skulle de bearbeide manuskriptet til sin egen variant, som de deretter skulle dramatisere. Lærer bisto alle gruppene underveis i øvingen, og bidro med å skaffe kostymer og rekvisitter.

$\AA ̊$ omarbeide manuset fra Peer Gynt, og deretter dramatisere dette, innebar at elevene måtte omforme sine egne inntrykk av stykket til egne uttrykk. I prosessen fikk de muligheten til å uttrykke hvordan de hadde forstått stykket, og til å uttrykke sine egne tolkninger. Etter å ha øvd inn sine ulike versjoner, fremførte elevene dramatiseringen for klassen og læreren i aulaen. Elever som ikke ønsket å stå på scenen kunne være regissører eller ha andre oppgaver i forbindelse med dramatiseringen, noe som gjaldt to elever. 


\section{Metodologiske overveielser}

Formålet med denne studien er å undersøke betydningen av estetiske uttrykksformer ut fra en bred referanseramme fremfor å undersøke det faglige utbyttet av undervisningen, og dermed synes det hensiktsmessig å studere feltet ut fra flere perspektiv gjennom et case-design (Merriam, 1998, s. 19). Ved å undersøke flere tid- og sted-bundne systemer (caser) i en realistisk setting over tid, var målet å samle inn detaljerte data ut fra flere ulike informasjonskilder (Creswell, 1998). Som en ikke-deltakende observatør, i betydningen at jeg ikke var deltakende i utforming eller gjennomføring av undervisningsoppleggene, fulgte jeg våren og høsten 2020 tre prosjekter der estetiske uttrykksformer var integrert i samfunnsfag, matematikk og norsk i 9. og 10. klasse.

I tråd med studiens case-design, er det som nevnt benyttet ulike datainnsamlingsmetoder, og materialet består av film, egne observasjonsnotater, semistrukturerte dybdeintervju med tre lærere, samt gruppeintervju og individuelle intervju med til sammen 28 elever. Utgangspunktet for observasjonen var å studere nærmere de situasjonene jeg opplevde som interessante underveis i prosjektene, for eksempel om elevene fremsto som engasjerte i de estetiske aktivitetene. Fra disse oppholdene har jeg observasjonsnotatene jeg skrev underveis. Imidlertid er det krevende å skape mening $\mathrm{i}$ det som skjer $\mathrm{i}$ klasserommet samtidig som det foregår, og derfor valgte jeg å filme i tillegg, slik at jeg kunne observere det som skjedde ved flere gangs avspilling.

Observasjon av klasseromsinteraksjoner ut fra det som skjer både verbalt og kroppslig kan gi en meningsfull inngang til forståelse (Johansson, 2016). Samtidig får man ikke direkte tilgang til individenes meninger og erfaringer, og derfor valgte jeg å intervjue deltakerne i tillegg. Ut fra det jeg fant interessant under observasjonen, utarbeidet jeg intervjuguidene for lærerne og elevene. Basert på observasjonsnotatene fra for eksempel matematikktimene, ønsket jeg at matematikklæreren skulle beskrive hvilke didaktiske vurderinger han la til grunn for å integrere tesselering i matematikk, og hva slags erfaringer han tok med seg videre etterpå.

De tre lærerne som deltok i studien var strategisk utvalgt (Flyvbjerg, 1991) på bakgrunn av sin lange erfaring med estetiske uttrykksformer i sine respektive fag. Alle lærerne er rundt 50 år og har mer enn 20 års erfaring som lærere. To av disse hadde jeg tidligere intervjuet i forbindelse med min masteroppgave om estetiske læringsprosesser, og jeg kjente derfor til at de hadde lang erfaring med å integrere estetiske uttrykksformer i sine fag norsk, religion, samfunnsfag, engelsk og fransk. Jeg tok kontakt med disse to via e-post og fortalte om prosjektet mitt. På spørsmål om de kjente til flere lærere som kunne egne seg, tipset de meg om at denne matematikklæreren hadde prosjekter de mente kunne være adekvate for undersøkelsen. Etter å ha etablert kontakt med alle tre, hadde vi høsten 2019 et møte der vi diskuterte undersøkelsen min i relasjon til deres 
undervisningsopplegg, og fant i fellesskap ut at de tre prosjektene de fortalte om var relevante for formålet.

I tillegg til lærernes perspektiv, ønsket jeg også å undersøke elevperspektivet. Før oppstart av observasjonene, fortalte jeg elevene om prosjektet mitt. På slutten av observasjonsperioden ble elevene spurt om de kunne tenke seg å bli intervjuet om de aktuelle estetiske uttrykksformene i de respektive fagene. Flere meldte seg da frivillig til deltakelse. For å gjøre spørsmålene mer konkrete for elevene, ble intervjuguiden knyttet til de konkrete estetiske uttrykksformene elevene hadde erfart, for eksempel hvordan de opplevde å dramatisere Ibsens Peer Gynt i norsktimene.

Intervjuene fikk stor plass i analysen, men filmene og observasjonsnotatene utgjorde også en vesentlig del av forståelsesgrunnlaget. Disse ga meg et inntrykk av atmosfæren i klasserommet, samspillet mellom lærere og elever, og mellom elevene. Dette opplevde jeg som nødvendig for å få et utfyllende bilde av deltakernes erfaringer og fortellinger i samtalene med dem.

Lærerne og 22 elever ble intervjuet på skolen, mens seks av elevene ble intervjuet via den digitale plattformen Zoom grunnet Covid-19-restriksjoner. De digitale intervjuene fungerte godt fordi elevene som meldte seg var komfortable med mediet. Jeg kan ikke i ettertid se at det var forskjeller mellom de digitale og de analoge intervjuene som kunne hatt betydning for resultatene fra studien. Alle intervjuene fant sted etter at prosjektene var fullførte. Samtalene kunne dermed adresseres direkte til prosjektene, noe jeg fant verdifullt for at vi skulle få en felles forståelse av temaet. I tillegg hadde vi da rukket å bli bedre kjent underveis, slik at atmosfæren i intervjusituasjonen opplevdes som mer avslappet enn den ellers kunne vært.

Studien er gjennomført i tråd med de etiske prinsippene som er fastsatt av Den nasjonale forskningsetiske komité for samfunnsvitenskap, humaniora, juss og teknologi (NESH, 2016), og er godkjent av Norsk senter for forskningsdata (NSD). Deltakerne ga sitt samtykke til å delta i studien etter å ha fått skriftlig og muntlig informasjon om hva det innebar å delta. Deltakerne og skolen er anonymisert, og deltakerne ble informert om at de når som helst kunne trekke seg fra studien uten konsekvenser for dem.

\section{Analyseprosess}

Etter datainnsamlingen ble alle intervjuopptakene og filmopptakene transkribert, og lagt inn på pc. I transkripsjonene ble språket gjort om til bokmål, uansett hvilken dialekt deltakerne hadde, fordi det ble lettere å hanskes med materialet da. I motsetning til intervjuene, inneholder transkripsjonene fra filmene angivelser for stillhet, høylytthet og utbrudd, for eksempel latter, fordi jeg vurderte at det hadde betydning for analysen å beskrive atmosfæren i klasserommet under observasjonene. De håndskrevne observasjonsnotatene ble også skrevet inn på pc, slik at alt materialet ble samlet digitalt. 
På grunn av studiens åpne utgangspunkt og et relativt omfangsrikt kvalitativt datamateriale, fant jeg det hensiktsmessig å anvende tematisk analyse som kategoriseringsverktøy (Braun \& Clarke, 2006). Tematisk analyse er ikke bundet til et spesielt epistemologisk eller teoretisk perspektiv, noe som gjør det til en fleksibel metode som kan anvendes for å identifisere, analysere og rapportere mønster eller tema ut fra det foreliggende datamaterialet (Maguire \& Delahunt, 2017).

Selv om jeg allerede under observasjonen startet det analytiske arbeidet, da grunnlaget for intervjuguidene ble lagt her, syntes det nødvendig å danne seg et helhetsinntrykk av hele datamaterialet. Dette gjorde jeg ved å se filmene og lese igjennom alt flere ganger, noe som ga et overblikk over hva som fremsto som vesentlig. Jeg forsøkte i hele denne induktive prosessen å være bevisst eventuelle fordommer knyttet til egen kultur og erfaringer (Gadamer, 2010), slik at jeg kunne gjenkjenne det når jeg møtte noe $\mathrm{i}$ materialet som tiltalte meg, eller som jeg kanskje ville oversett fordi det ikke gjorde det. Etter å ha undervist i teoretiske fag på ungdomstrinnet i 26 år, og hatt en spesiell interesse for estetiske uttrykksformer, hadde jeg noen fordommer og hypoteser. Et eksempel fra egen erfaring var at jeg oppfattet estetiske uttrykksformer som engasjerende for elevene, noe jeg forsøkte å være bevisst på underveis i analysen. Ved å konsultere teori underveis forsøkte jeg å skille mellom bekreftelse av egne fordommer og substansielle funn i materialet.

Neste skritt var å utføre en innledende koding ved å markere det som fremsto som interessant ut fra forskningsspørsmålet. På bakgrunn av egne hypoteser og fordommer prøvde jeg imidlertid å være åpen for at deltakerne kunne bringe inn noe som var uventet, og som brøt med eventuelle forventninger. For å lete etter mulige temaer, lette jeg i første omgang etter det som fremsto som fremtredende i hele materialet, men også det som ble betraktet som interessant ut fra problemstillingen, ble etter hvert vurdert (Braun \& Clarke, 2006). I denne fasen ble Nvivo brukt, da det var et stort antall koder og mulige tema som skulle reduseres, og det var mer oversiktlig å samle alt digitalt.

Etter flere runder med vurdering av mulige tema, ble antallet tema redusert ut fra en gransking av hvilke koder og tema som kunne slås sammen fordi de egentlig handlet om det samme. For eksempel kategoriserte jeg innledningsvis engasjement og glede som et eget tema, men konkluderte med at det kunne slås sammen med det som etter hvert ble til fravær av stress. Mange elever trakk selv frem i intervjuene at de «ikke var så stressa» ved estetisk opplevelse og utfoldelse, så jeg begynte å orientere meg mot nettopp stresselementet underveis i analysen. I denne fasen gikk jeg over fra Nvivo til manuell analyse med lapper og fargekoder.

Ytterligere runder med vurdering av koder og tema resulterte i at fravær av stress syntes å fremstå som et overordnet tema for flere av de kodene og temaene jeg hadde identifisert i hele datamaterialet i løpet av mange runder. Å glemme tiden, som var et tema jeg hadde identifisert innledningsvis, vurderte jeg etter 
hvert som en komponent av fravær av stress fordi det syntes å handle om en intens tilstedeværelse i øyeblikket, noe som kunne relateres til fravær av stress. På samme måte ble frihet, et annet tema som ble kategorisert tidlig i prosessen, etter hvert vurdert som en komponent av fravær av stress fordi det syntes å handle om frihet til å selv bestemme hva og hvordan elevene skulle mediere sine inntrykk, i motsetning til å finne «riktige svar» på en oppgave. Samtidig var disse to sistnevnte temaene av ulik kvalitet seg imellom, og dermed konkluderte jeg med at dialogen mellom disse temaene bidro til å nyansere hva som kunne relateres til fravær av stress, og kategoriserte dem som undertema. Gjennom en hermeneutisk frem- og- tilbake-bevegelse mellom datamaterialet og det jeg tolket som relevant litteratur (Alvesson \& Sköldberg, 2008; Tjora, 2017), ble de to undertemaene endelig definert og navngitt som henholdsvis overskridelse og selvbestemmelse. I presentasjonen av resultatene under, vil sammenhengen mellom hovedtemaet og de to undertemaene utdypes nærmere.

\section{Resultater}

I det følgende vil de to undertemaene presenteres og knyttes til det empiriske materialet i undersøkelsen. Undertemaene overskridelse og selvbestemmelse vil analyseres hver for seg, i lys av det teoretiske rammeverket for studien, og relateres til det overordnede temaet fravær av stress.

\section{Overskridelse}

Et slående trekk ved elevenes deltakelse i de estetiske aktivitetene, er at fokuset synes å ligge på selve opplevelsesøyeblikket i her - og nå - situasjonen (Willbergh, 2008), noe som kan knyttes til at opplevelsesintensitet og det aktivtsanselige står sentralt ved estetisk aktivitet (Næss, 1976, 1999; Østern et al., 2019). Elevene fremstår på denne måten som fordypet i de aktivitetene de deltar i. Flere av elevene beskriver et følelsesmessig engasjement når de blir bedt om å fortelle hvordan de opplever de ulike prosjektene. Beskrivelser som gøy, artig og spennende er adjektiv som går igjen blant elevene, slik denne eleven forteller fra dramatisering i norsk:

Når vi har hatt skuespill, oi, ja, liksom da husker jeg det, liksom (...) fordi det er liksom noe mer med skuespill, så liksom lærer man mer av det... Når det er artig, så husker du det oftere også, så da er det en artigere måte å lære på.

At denne eleven synes det er noe mer med skuespill, kan indikere at det aktivtsanselige aspektet ved å dramatisere skaper en opplevelsesintensitet som denne eleven engasjeres følelsesmessig av, og at det dermed oppleves som artig, og noe vedkommende husker bedre. Det er imidlertid ikke bare positive følelser som 
trekkes frem for å beskrive det følelsesmessige engasjement blant elevene når de dramatiserer, men også det ukomfortable og flaue, slik denne eleven forteller om:

Det kan også være litt sånn ukomfortabelt hvis vi lever oss for mye inn i det (...) Det kan jo være litt flaut når du må stå og liksom... Når du må leve deg inn og sånn (...) Men det er jo litt fett å liksom utforske... Man kan jo ikke bare være i komfortsonen.

At elevene trekker frem følelsesmessig engasjement, enten i form av det positive eller mer ukomfortable, som karakteristisk for dramatiseringen, kan forstås ut fra det risikofylte og uforutsigbare elementet som kjennetegner estetisk aktivitet, og at dette kan tiltrekke og fascinere dem (Gadamer, 2010). Tiltrekningen og fascinasjonen kan relateres til en estetisk erfaring, som skiller seg fra rutinemessige erfaringer ved at de har en emosjonell kvalitet som berører elevene (Dewey, 1938/1974, 1934/2008).

Opplevelsesintensitet var også et påfallende trekk under observasjonene i klasserommene, og er et inntrykk som ytterligere blir understøttet av å studere filmene. Denne diskusjonen mellom elevene i samfunnsfagtimen kan være et eksempel på opplevelsesintensitet i tolkningen av billedkunstverket French Troops Resting:

Elev 1: Dette er vann, og her er himmelen

Elev 2: Nei, det der er ikke vann

Elev 1: Hva er dette, da? Hvorfor er det hvitt her, da?

Elev 2: Kanskje det er frost?

Elev 3: Men det er så rart... Hvorfor skal det være is når det er gusjegrønt gress ved siden av?

Elev 2: Men dette er ikke en sky

Elev 1: Det kan jo være det?

Elev 3: Men skyer går jo ikke den veien!

Den høylytte diskusjonen som kunne observeres mellom elevene kan være et resultat av at bildet gir dem en direkte, sanselig og intuitiv opplevelse (NordbergSchulz, 1997; Næss, 1976), og at dette engasjerer dem følelsesmessig, slik at de synes å være totalt til stede i øyeblikket. Bildets flertydighet og åpenhet for tolkning (Drotner, 1991) engasjerer elevene, trolig fordi de kan relatere det til egne erfaringer (Dewey, 1902/1964)

Atmosfæren i klasserommene under observasjonen av alle de tre prosjektene var preget av en slående intensitet og inderlighet, der elevene syntes å være oppslukte av aktivitetene i seg selv (Gadamer, 2010). Opplevelsen av de ulike dekorasjonsmønstrene i Alhambra i matematikktimen vakte stor begeistring og forbløffelse blant elevene, og ledet til ivrige samtaler både rundt det estetiske og det matematiske ved mønstrene. Mange var også opptatt av det praktiske; hvordan det rett og slett var mulig å dekorere så store områder med så stor nøyaktighet, og at dette ble gjort for så mange år siden. Den sanselige erfaringen av kunstverkene i Alhambra syntes å fascinere elevene på en slik måte at de ledet til en 
opplevelsesintensitet (Næss, 1976), som kan tolkes som en følelsesmessig indre drivkraft (Næss, 1999), der fokuset ligger på selve opplevelsesøyeblikket (Willbergh, 2008).

På samme måte var atmosfæren i klasserommet påfallende intens da elevene skulle skape egne mønster i matematikktimen, etter inspirasjon fra mønstrene i Alhambra. Samtlige elever satt da dypt konsentrerte i arbeidet, og stillheten ble kun avbrutt av at elevene innimellom ba lærer om farger for å fargelegge mønstrene sine. Da timen var over, ville mange sitte igjen i klasserommet for å gjøre ferdig arbeidet sitt. Ut fra det jeg oppfattet som en intens opplevelsesintensitet (Næss, 1976) under denne skapende aktiviteten i klasserommet, syntes det som den sanselige opplevelsen av mønstrene i Alhambra ga inspirasjon i arbeidet med å skape egne mønster.

Den opplevelsesintensiteten, inderligheten og fascinasjonen som er beskrevet i disse utdragene fra datamaterialet, kan tolkes i lys av at de estetiske aktivitetene synes å lede til en form for hengivelse, i tråd med det Gadamer (2010) betegner som at det er selve leken - den estetiske aktiviteten - som blir subjektet, og holder elevene «i spill». Slik kan de estetiske aktivitetene ha et overskridende eller transcenderende element som gjør at elevene oppslukes på en så intens måte at de kan glemme tiden og seg selv. I det formskapende arbeidet synes det transcenderende elementet ved estetisk aktivitet å være present, slik denne eleven forteller om fra arbeidet med å skape et estetisk uttrykk i samfunnsfag:

Ja, ofte når.. når jeg satt og jobbet med dette prosjektet, så glemte jeg nesten at det var et prosjekt, at det var på en måte skole. Det var litt mer sånn der at jeg hadde lyst til å jobbe med det.

I tillegg trekker flere av elevene frem at de til en viss grad glemmer at deres prestasjoner er gjenstand for vurdering når de deltar i estetisk aktivitet, slik denne eleven fortalte om i forbindelse med dramatisering av norsk: «Vi tenker mye mindre på at vi skal vurderes når vi dramatiserer. Det er mye mer gøy og spennende». I lys av det overskridende elementet ved estetisk aktivitet (Gadamer, 2010), og en orientering mot øyeblikkets her og nå (Willbergh, 2008), kan det være rimelig å anta at elevene opplever fravær av negativt stress ved estetiske opplevelser, eller når de utfolder seg i estetisk aktivitet.

\section{Selvbestemmelse}

Gjennomgangsmelodien blant elevene da de ble bedt om å fortelle hva de tenker om betydningen av estetisk opplevelse og utfoldelse i teoretiske fag, er å huske det bedre, lære mer og å forstå det bedre, noe de kontrasterer med de det kaller «vanlige skolemetoder», som de hevder er lesing, skriving, muntlige presentasjoner og skriftlige prøver. Denne eleven forteller at det å jobbe med å skape et estetisk uttrykk fra 1 . verdenskrig medfører mindre stress og mer glede enn når hun jobber mot tradisjonelle skriftlige eller muntlige prøver: 
Når du... altså før prøver og sånn, så er jeg egentlig litt mer stressa også, at jeg: «Nei, jeg må huske det og jeg må huske det», mens her så var det litt mer sånn.. Her husket jeg det egentlig litt bedre fordi at jeg ikke var så stressa (...) Jeg synes egentlig at jeg... at jeg lærte nesten litt bedre av det. Fordi at ofte på prøver, så jobber du så hardt med det, og så bare svarer du, men så egentlig - så husker du ikke så mye av det etterpå.

Dette kan tolkes i lys av at det skapende elementet gjør arbeidet mer personlig for henne ved at det hun skapte i samfunnsfag ikke bare er en representasjon av det hun har lest om krigen, men er et uttrykk for hvordan hun har forstått stoffet (Lindstrand \& Selander, 2009). Dermed kan hun knytte arbeidet til sin bakgrunnskunnskap og sine egne interessefelt (Dewey, 1902/1964). Karakteristisk for estetisk symbolsk form er det flertydige (Austring \& Sørensen, 2006), noe som kan forklare at hun opplever det som mindre stressende enn om hun skal finne riktige svar. Estetiske uttrykksformer tilbyr flere tolkningsmuligheter og dermed mindre fokus på det som er «feil».

Det flertydige ved estetiske uttrykksformer ledet også til engasjerte diskusjoner mellom elevene da de gruppevis skulle tolke Bukkerittet fra Ibsens Peer Gynt, og gjøre manuskriptet om til sitt eget ved å omskrive sekvensen ut fra sin egen tolkning, og deretter iscenesette den. Her fremstår det nok en gang som at det flertydige inviterer elevene til å delta i diskusjonen på sine egne premisser, uten at de må forholde seg til riktige svar, og at dette engasjerer dem. De kan ta i bruk sine egne erfaringer, og har frihet til å bestemme selv hvordan de vil forberede og fremføre iscenesettelsen, forutsatt at de forholder seg til de rammene dramaformen setter. I intervjuene i etterkant knyttet flere av elevene engasjementet sitt til det å bestemme selv hvordan de ville mediere sine uttrykk, slik denne eleven forteller: «Ja, det var gøy. Interessant. Liksom få manuset og gjøre det til sitt eget. $\AA$ vise frem sin egen tolkning av Peer Gynt, da». Tolkningsarbeidet og de valgene elevene må ta i den skapende prosessen, krever selvstendige og faglig funderte avgjørelser, der de får muligheten til å opptre som autonome aktører i norsktimene.

På tross av at de setter pris på friheten til å bestemme selv, opplever også flere av elevene at friheten kan være utfordrende og krevende, slik denne eleven beskriver arbeidet med samfunnsfagprosjektet:

Jeg ville sagt at hvis du tenker du skal lese en bok om det og så skrive rapport, så blir det på en måte lettere (...) Når man får bestemme selv, så blir det jo veldig vanskelig å finne ut... hva vi klarer å gjøre. (...) Det var definitivt en utfordring.

Selvbestemmelse synes ikke for elevene å bety at de slipper lettere unna arbeidet, men tvert imot at det krever noe mer av dem, noe som også understøttes av denne elevens uttalelse fra dramatiseringen i norsk: «Det enkleste er jo å bare få liksom manuset skrevet, liksom, men det er jo dette med at det er litt gøy å kunne gjøre det til sitt eget, og velge ut det vi vil ha med, da». Friheten til å skape noe selv synes å kreve noe av dem som de likevel ikke karakteriserer som stress, på tross 
av at det kan medføre ubehag og usikkerhet i form av at de utfordres både faglig og personlig. Det er mulig at de tiltrekkes og fascineres av risikoelementet ved estetisk utfoldelse (Gadamer, 2010), og at muligheten til å relatere stoffet til det personlige (Lindstrand \& Selander, 2009), kan redusere opplevelsen av stress når de engasjeres i estetisk utfoldelse. Estetiske erfaringer kan oppleves som emosjonelt tilfredsstillende når delene i erfaringen har en indre sammenheng og når en fullbyrdelse (Dewey, 1938/1974, 1934/2008), noe som kan belyse hvorfor denne eleven trekker frem stolthet ved fullbyrdelsen av prosjektet i samfunnsfag, der hun bygget en modell av en scene fra 1 . verdenskrig:

Og det er også noe med at - hvis jeg har en prøve, og uansett om det går bra eller dårlig, så går jeg ikke og snakker om at: «Å, jeg gjorde det bra eller dårlig på den prøven» eller at jeg var stolt fordi jeg klarte den prøven. Men prosjektet her, når du faktisk har laget noe, så kan jeg si sånn: «Jeg blir stolt fordi jeg klarte det», og jeg vil fortelle det videre, ikke sant? Og da lærer man jo mer av det, så jeg tror det blir på en måte litt sånn at man har gjort noe, og da kan man fortelle det videre - at man har skapt noe.

Sitatet kan forstås ut fra at den emosjonelle opplevelsen av stolthet ved å skape noe selv kontrer utfordringene som ligger i å bestemme selv hva og hvordan det kreative produktet skal realiseres, som nevnt over, og at den estetiske erfaringen (Dewey, 1938/1974, 1934/2008) trolig bidrar til å dempe en mulig opplevelse av stress.

At estetisk opplevelse og utfoldelse gir mulighet til å ivareta kontekstuelle forhold som elevenes interesser, evner og kultur (Dewey, 1902/1964; Drotner, 1991; Lindstrand \& Selander, 2009), og at estetisk aktivitet kan relateres til selvbestemmelse og opplevelse av frihet (Hohr, 2015; Klafki, 2000), kan gi en forståelse av at elevene trekker frem fravær av stress når de forteller hvordan de opplever estetiske uttrykksformer i teorifagene.

\section{Avsluttende diskusjon}

Basert på analysen av datamaterialet i denne studien, kan resultatene karakteriseres som at estetiske uttrykksformer i fagene samfunnsfag, matematikk og norsk på ungdomstrinnet kan være fruktbare fordi de bidrar til fravær av negativt stress i undervisningen. Fravær av negativt stress synes for det første å kunne relateres til det overskridende elementet ved estetisk opplevelse og utfoldelse, der man fordypes i og oppslukes av selve aktiviteten, og glemmer både tiden og seg selv. For det andre synes fravær av stress å kunne relateres til selvbestemmelse og frihet, i form av at estetisk symbolsk form er flertydig og gir rom for tolkning, slik at elevene kan relatere lærestoffet til det personlige.

Resultatene er i tråd med eksisterende undersøkelser som er gjort på estetiske uttrykksformer i teoretiske fag på videregående trinn, der det også trekkes frem at elevene opplever at de lærer bedre, og at det skapes større interesse i 
undervisningen når kognitive erfaringer suppleres med praktiske og emosjonelle erfaringer (Kvam \& Ulvik, 2019; Ulvik, 2020). Denne studiens bidrag til forskningsfeltet er å nyansere den eksisterende kunnskapen ved å løfte frem at estetisk aktivitet kan relateres til fravær av negativt stress på ungdomstrinnet. I det følgende vil resultatene diskuteres samlet, i lys av den nåtidige skolekonteksten i Norge.

Et sentralt prinsipp i overordnet del av læreplanen er danning av hele mennesket (Kunnskapsdepartementet, 2020, s. 13). Hele mennesket kan forstås som at både det kognitive, kroppslige og emosjonelle skal ivaretas i skolen. I tråd med dette har også estetisk opplevelse og utfoldelse historisk vært begrunnet ut fra idéen om allmenndannelse i betydningen danning av hele mennesket (Humboldt, 2000). I denne sammenheng handler det blant annet om å aktivere både hånd, hode og hjerte i undervisningen (Pestalozzi, 1894).

Et vesentlig poeng i arbeidet med fagfornyelsen, er å skape sterkere sammenheng mellom verdiene fra overordnet del av læreplanen og arbeidet med fagplanene (NOU 2015:8, 2015). Resultatene fra denne undersøkelsen kan tyde på at det kan være fruktbart å vektlegge sanselige, kroppslige og emosjonelle erfaringer også i teoretiske fag. $\AA$ vektlegge emosjonelle elementer som engasjement, glede og fravær av stress, som elevene trekker frem i denne studien, kan synes særlig relevant i vår tid, der mange elever rapporterer om stress og mangel på motivasjon i sin skolehverdag (Bakken, 2020). Mangel på motivasjon, glede og engasjement i undervisningen knyttes i forskning til opplevelse av negativt stress (Lillejord, 2017), noe som kan skape et lite fruktbart læringsmiljø. Læreres profesjonskompetanse består blant annet i å finne en balanse mellom positivt og negativt stress, der positivt stress er relatert til at det er balanse mellom de krav man møter i en situasjon og tilgjengelige personlige og sosiale ressurser. Elevene i denne undersøkelsen trekker frem at estetisk aktivitet kan være mer utfordrende og mer arbeidskrevende enn det de kaller vanlige skolemetoder, men at det ikke oppleves som negativt stress. Dette kan forstås som at de får utfordringer de er i stand til å takle, og at estetisk aktivitet skaper en tilstedeværelse i øyeblikket som er basert på en dialog mellom det å oppslukes av selve aktiviteten og elevenes opplevelse av selvbestemmelse i aktiviteten. $\AA$ oppleve eller utfolde seg i estetisk aktivitet kan bringe sammen kroppslige, kognitive og emosjonelle erfaringer i en helhetlig estetisk erfaring (Dewey, 1934/2008). Denne opplevelsen kan berøre elevene, slik at stresselementet blir mindre fremtredende, noe som igjen kan bidra til et mer fruktbart læringsmiljø, der skolens flerdimensjonale mål aktualiseres (Biesta, 2011). I tillegg til å sørge for at elevene får nødvendig kunnskap og kompetanse for fremtiden, er skolen også et sted der elevene skal fungere sammen med andre i et fellesskap, og et sted for menneskelig vekst og utvikling (Eisner, 2002).

Det kan imidlertid være en utfordring å få gjennomslag for tanken om å aktivere og engasjere hele mennesket $\mathrm{i}$ alle fag i den norske utdanningsdiskursen, som de siste 20 årene har dreid mot en utbytteorientert utdanningsfilosofi (Imsen, 
2012; Prøitz \& Nordin, 2019). Spesielt utfordrende kan det være når skolen betraktes som en investering i en global økonomisk konkurranse (Løvlie, 2013). I ytterste konsekvens kan dette lede til en større grad av ensretting og standardisering av undervisningen, som et ledd i å gjøre utdanningen sterk, sikker og forutsigbar, og på den måten minske risiko på alle nivå (Biesta, 2014). Ut fra denne undersøkelsen ligger imidlertid verdien av estetiske uttrykksformer nettopp i deres åpenhet for kontekstuelle forhold som elevenes egne interesser, evner og kultur.

Prosessene elevene inviteres til å delta i når de engasjeres gjennom estetiske uttrykksformer har som vist vesentlig verdi i denne undersøkelsen, og resultatene aktualiserer allmenndidaktiske spørsmål som forholdet mellom produkt og prosess i undervisningen (Prøitz \& Nordin, 2019). I en resultatorientert utdanningsdiskurs tillegges prosessene elevene deltar i mindre verdi. En implikasjon av denne studien kan i denne sammenheng være at resultatene bidrar til å utfordre målstyringsrasjonalet ved å aktualisere begrepet ekspressive mål (Eisner, 1994). Ekspressive mål innebærer å planlegge aktiviteter som ikke har eksplisitte og presist formulerte, forhåndsbestemte mål, men som likevel kan ha sin berettigelse i undervisningen fordi prosessene i seg selv er fruktbare. Enhver prosess som gjøres tilgjengelig for elevene i undervisningen har muligheter og begrensninger (Eisner, 1990). Gjennom aktivt skapende estetisk virksomhet, og gjennom møtet med andres estetiske uttrykk i alle fag, ligger mulighetene i at man får sanselige, følelsesmessige og refleksive erfaringer som er fruktbare - også uten at disse nødvendigvis knyttes til forhåndsbestemte, spesifikt formulerte mål for læringsutbyttet i faget. Når antall kompetansemål i hvert fag nå er redusert i forbindelse med fagfornyelsen (Kunnskapsdepartementet, 2020; Meld. St. 28 (2015-2016)), kan det være et godt utgangspunkt for å vie ekspressive mål større oppmerksomhet i den didaktiske diskursen.

På tross av at det å integrere estetiske uttrykksformer i alle fag har en lang tradisjon i den pedagogiske idéhistorien, og har hatt stor betydning i den skandinaviske lærerutdanningen (Hohr \& Pedersen, 1996), er det mye som tyder på at det er en reell fare for at færre lærere i dag enn tidligere har kunnskap om estetiske elementer i utdanningen, og da spesielt i mer teoretiske fag. Etter at det ble valgfritt med fordypning i estetiske fag i lærerutdanningene fra 2003, velger et betydelig antall lærerstudenter bort estetiske fag i sin utdanning (Brekke \& Willbergh, 2017; Espeland, Allern, Carlsen \& Kalsnes, 2011; Smestad, 2014). I tillegg synes som nevnt estetiske uttrykksformer å være lite systematisk integrert i grunnskolelærerutdanningene (By et al., 2020). Resultatene fra denne undersøkelsen kan dermed også ha implikasjoner for lærerutdanningene, fordi studien synliggjør at det kan være fruktbart at lærere har kunnskap om det estetiske i opplæringen, uavhengig av hvilke fag man underviser i.

En begrensning ved denne studien er at datamaterialet er basert på et strategisk utvalg, og at resultatene ikke nødvendigvis er overførbare til andre undervisningssituasjoner. Studien løfter frem de erfaringene og opplevelsene 
akkurat disse lærerne og elevene har hatt, og det kan ikke konkluderes med at det er en direkte sammenheng mellom de estetiske aktivitetene og de fruktbare resultatene. Det må også tas høyde for at min deltakelse som observatør kan ha påvirket deltakerne til å opptre annerledes enn de ellers ville gjort (Postholm, 2010).

På den annen side har studien sin verdi gjennom å eksemplifisere hvordan og hvorfor det kan være fruktbart å integrere estetiske uttrykksformer i teoretiske fag på ungdomstrinnet. På denne måten kan studien bidra til å skape refleksjon rundt betydningen av det estetiske i opplæringen, og mulig inspirasjon til å inkludere estetiske uttrykksformer i egen undervisning - også i teoretiske fag. Studien kan dermed bidra med å skape grunnlag for refleksjon til de lærere, skoleledere og studenter som er interesserte i estetiske elementer i skole og opplæring.

\section{Konklusjon}

Både forskning og styringsdokumenter for skolen oppfordrer til å integrere estetiske uttrykksformer i alle fag (Bamford, 2008; Kunnskapsdepartementet, 2020; Lindstrand \& Selander, 2009; Østern et al., 2019). Samtidig er estetiske elementer i utdanningen under press, grunnet en økende resultatorientering i den norske skolen i de siste 20 årene (Allern, 2011; Prøitz \& Nordin, 2019). På bakgrunn av dette, var forskningsspørsmålet for denne undersøkelsen: Hvordan kan estetiske uttrykksformer være fruktbare for undervisningen i teoretiske fag på ungdomstrinnet?

I studien løftes det frem at estetiske uttrykksformer kan være fruktbare i teoretiske fag fordi estetisk aktivitet kan relateres til fravær av negativt stress i undervisningen. Fravær av negativt stress synes for det første å ha sammenheng med det overskridende elementet ved estetisk opplevelse og utfoldelse, der man fordypes i og oppslukes av selve aktiviteten, og glemmer både tiden og seg selv (Gadamer, 2010). For det andre synes fravær av negativt stress å kunne relateres til selvbestemmelse, på grunnlag av at estetisk symbolsk form er flertydig og gir mer frihet og rom for tolkning, slik at elevene kan relatere lærestoffet til det personlige (Austring \& Sørensen, 2006; Austring \& Sørensen, 2019; Drotner, 1991). At lærere legger til rette for å redusere elevenes opplevelse av negativt stress i undervisningen har betydning for å skape et fruktbart læringsmiljø. Læreres profesjonskompetanse handler i denne sammenhengen blant annet om å finne en balanse mellom positivt og negativt stress (Lillejord, 2017). A være oppmerksom på stresselementet synes særlig relevant i vår tid, der mange elever rapporterer om stress og mangel på motivasjon i sin skolehverdag (Bakken, 2020). Når danning av hele mennesket er et sentralt prinsipp i læreplanene, både på overordnet nivå og i arbeidet med fagene (Kunnskapsdepartementet, 2020), synes det fruktbart at estetisk aktivitet, der kroppslige, kognitive og emosjonelle erfaringer spiller sammen, får en plass også i teoretiske fag. 
For å videreutvikle forskningsfeltet som er knyttet til den estetiske dimensjonen i utdanning, er det behov for ytterligere forskning på temaet. Denne studien antyder blant annet at estetiske uttrykksformer i undervisningen kan være fruktbare i et mangfolds- og inkluderingsperspektiv, på bakgrunn av de estetiske uttrykksformenes åpenhet for kontekstuelle forhold som elevenes interesser, evner og kultur. Tatt i betraktning at en stadig større andel elever i grunnskolen faller utenfor fellesskapet i den ordinære opplæringen (Utdanningsdirektoratet, 2021), og at dette ifølge Terje Ogden og Thomas Nordahl i stor grad skyldes økt fokus på prestasjon i skolen (Holterman, 2021), synes det relevant å videreutvikle forskning på betydningen av estetiske uttrykksformer i et mangfolds - og inkluderingsperspektiv.

\section{Om forfatteren}

Hanne Alterhaug er stipendiat i ved Norges teknisk-naturvitenskapelige universitet (NTNU) og er medlem av forskningsgruppen BULKIS (Barn og unges livskvalitet i skolen). I doktorgradsprosjektet utforskes betydningen av estetisk opplevelse og utfoldelse på ungdomstrinnet.

Institusjonstilknytning: Institutt for lærerutdanning, Norges teknisknaturvitenskapelige universitet (NTNU), 7491 Trondheim-

E-post: hanne.alterhaug@ntnu.no

\section{Referanser}

Allern, T.-H. (2011). Er det plass for kunstfag i skolen etter PISA? Kunstløftet/Kulturrådet. Hentet 19.11. fra http://www.kulturradet.no/kunstloftet/vis-artikkel/-/kl-artikkel-allernmaitekst

Alvesson, M. \& Sköldberg, K. (2008). Tolkning och reflektion. Vetenskapsfilosofi och kvalitativ metod. Narayana Press.

Austring, B. D. \& Sørensen, M. (2006). Astetik og lcering. Grundbog om cestetiske lcereprocesser. Reitzel.

Austring, B. D. \& Sørensen, M. (2019). Æstetiske læreprocesser i skolen. I K. H. Karlsen \& G. B. Bjørnstad (Red.), Skaperglede, engasjement og utforskertrang. Universitetsforlaget.

Bakken, A. (2020). Ungdata 2020. Nasjonale resultater. OsloMet. https://fagarkivet.oslomet.no/bitstream/handle/20.500.12199/6415/Ungdata-NOVARapport\%2016-20.pdf?sequence $=1$ \&isAllowed $=y$

Bamford, A. (2008). Wow-faktoren. Globalt forskningskompendium, om kunstfagenes betydning i utdanning. Musikk i skolen.

Bamford, A. (2012). Kunst- og kulturopplering i Norge 2010/2011 : sammendrag på norsk av kartleggingen "Arts and cultural education in Norway". Nasjonalt senter for kunst og kultur i opplæringen.

Biesta, G. J. J. (2011). God uddannelse i målingens tidsalder - etik, politik og demokrati. Forlaget Klim. 
Biesta, G. J. J. (2020). Educational Research. An Unorthodox Introduction. Bloomsbury Publishing Plc.

Biesta, G. J., J. (2014). Utdanningens vidunderlige risiko. Vigmostad \& Bjørke AS.

Braun, V. \& Clarke, V. (2006). Using thematic analysis in psychology. Qualitative Research in Psychology, 3, 77-101. https://doi.org/10.1191/1478088706qp063oa

Brekke, B. \& Willbergh, I. (2017). Frihet, fantasi og utfoldelse. En kvalitativ studie av estetiske arbeidsformer i lærerutdanningene. Norsk tidsskrift for pedagogikk og kritikk, 3(1). https://doi.org/ https://doi.org/10.23865/ntpk.v3.554

By, I. Å., Holthe, A., Lie, C., Sandven, J., Vestad, I. L. \& Birkeland, I. M. (2020). Estetiske læringsprosesser i grunnskolelcererutdanningene. Helhetlig, integrert og forskningsbasert? (s. 77- 80). Universitetet i Sørøst-Norge (USN). https://www.regjeringen.no/contentassets/ea18f23415a14c8faaf7bc869022afc2/estetiskelaringsprosesser-i-grunnskolelarerutdanningene.pdf

Chemi, T. (2010). Artfulnes i Vejle. Kvalitativt studie i folkeskolen, 2009-2010. V. kommune \& U. R. Lab.

Creswell, J. D. (1998). Qualitative Inquiry and Research Design. Choosing Among Five Traditions. Thousand Oaks: Sage Publications, Inc.

Dewey, J. (1902/1964). Barnet og læreplanen (B. Christensen, Overs.). I R. Archambault (Red.), John Dewey on Education. Selected Writings.

Dewey, J. (1934). Art as Experience. The Berkley Publishing Group.

Dewey, J. (1974). Erfaring og opdragelse. Christian Ejlers' Forlag. (Opprinnelig utgitt 1938)

Dewey, J. (1997). Demokrati och utbildning. Daidalos AB.

Dewey, J. (2008). Å gjøre en erfaring IEstetisk teori. En antologi (s. 196-213 ). Universitetsforlaget. (Opprinnelig utgitt 1934)

Drotner, K. (1991). At skabe sig selv: ungdom, estetikk, pedagogikk. Gyldendal.

Eisner, E. (1990). A Development Agenda. Creative Curriculum Development and Practice. Journal of Curriculum and Supervision, 6, 62-73.

Eisner, E. (1994). The Educational Imagination. On the Design and Evaluation of School Programs. Macmillan Publishing Co., Inc.

Eisner, E. (2002). From episteme to phronesis to artistry in the study and improvement of teaching. Teaching and teacher education, 18, 375- 385.

Eriksson, S. A., Heggstad, K. M., Heggstad, K. \& Cziboly, Á. (2014). 'Rolling the DICE'. Introduction to the international research project Drama Improves Lisbon Key Competences in Education. Research in drama education, 19(4), 403-408. https://doi.org/10.1080/13569783.2014.954814

Espeland, M., Allern, T. H., Carlsen, K. \& Kalsnes, S. (2011). Praktiske og estetiske fag og lererutdanning (Bd. 1). HSH-rapport

Flyvbjerg, B. (1991). Rationalitet og magt. Bind 1: Det konkretes videnskab. Akademisk forlag.

Gadamer, H. G. (2010). Sannhet og metode. Pax Forlag A/S.

Haug, P. (2003). Evaluering av L97: Sluttrapport frå styret for Program for evaluering av Reform 97/Evaluating Reform 97: Final report from the executive for Program for evaluating of Reform 97. Noregs forskningsråd.

Hilt, L. T., Riese, H. \& Søreide, G. E. (2019). Narrow identity resources for future students: The 21st century skills movement encounters the Norwegian education policy context. Journal of Curriculum Studies, 51(3), 384-402. https://doi.org/10.1080/00220272.2018.1502356

Hodgson, J., Rønning, W. \& Tomlinson, P. (2012). Sammenhengen Mellom Undervisning og Lœring. En studie av læreres praksis og deres tenkning under Kunnskapsløftet. Sluttrapport. 
NF-rapport nr 4. Nordlandsforskning. https://www.udir.no/globalassets/filer/tall-og-

forskning/rapporter/2012/smul.pdf

Hohr \& Pedersen, K. (1996). Perspektiver på cestetiske læreprocesser. Dansklærerforeningen.

Hohr, H. (2015). Kunst og estetisk oppdragelse. Nordisk tidsskrift for pedagogikk og kritikk, 1. https://doi.org/ https://doi.org/10.17585/ntpk.v1.113

Holterman, S. (2021). Stadig flere barn på spesialskoler. Utdanning, 1, 8-9. https://www.utdanningsnytt.no/gsi-spesialskoler/stadig-flere-barn-paspesialskoler/266925

Humboldt, W. v. (2000). Theory of Bildung. I I. Westbury, K. Riquarts \& S. T. Hopman (Red.), Teaching as a reflective practice: The German didaktik tradition (s. 57-61). L. Erlbaum Associates.

Imsen, G. (2012). Kompetansemål som læreplanlogikk. I A. G. Eikseth, C. F. Dons \& N. Garm (Red.), Utdanning mellom styring og danning. Et nordisk panorama (s. 97-113). Akademika Forlag.

Johansson, K. (2016). Mellom hermeneutikk og fenomenologi - et essay om vitenskapsteori. Musikkterapi, 2.

Klafki, W. (2000). Didaktik Analysis as the Core of Preparation of Instruction. I I. Westbury, S. Hopman \& K. Riquarts (Red.), Teaching as a Reflective Practice. The German Didaktik Tradition (s. 139-149). Lawrence Erlbaum Associates.

Klette, K. (2003). Klasserommets praksisformer etter Reform 97. Universitetet i Oslo, Det utdanningsvitenskapelige fakultet og Norges forskningsråd. https://www.duo.uio.no/bitstream/handle/10852/32308/Reform97_Rapp_1_03_web.pdf?s equence $=1 \&$ is Allowed $=y$

Klette, K. (2020). Hva vet vi om god undervisning? Rapport fra klasseromsforskningen. I R. J. Krumsvik \& R. Säljö (Red.), Praktisk-pedagogisk utdanning: en antologi (s. 183-214). Fagbokforlaget.

Kunnskapsdepartementet. (2019). Skaperglede, engasjement og utforskertrang. Praktisk og estetisk innhold i barnehage, skole og lærerutdanning. Kunnskapsdepartementet. https://www.regjeringen.no/contentassets/201001d9f9f24870aa5c06ce9b12c8be/skapergl ede-engasjement--og-utforskertrang.pdf

Kunnskapsdepartementet. (2020). Læreplanverket for KUNNSKAPSLØFTET 2020. Grunnskolen. PEDLEX.

Kvam, E. K. \& Ulvik, M. (2019). Students perspectives' on teaching. The experience of teaching. Teachers' work in a tension between student perspectives and educational policy. European Conference on Educational Policy (ECER), Hamburg, Germany.

Lewis, T. E. (2012). The Aesthetics of Education. Bloomsbury Academic.

Lillejord, S. (2017). Stress i skolen: en systematisk kunnskapsoversikt. Kunnskapssenter for utdanning; Norges Forskningsråd.

Lindstrand, F. \& Selander, S. (2009). Förord. I F. Lindstrand \& S. Selander (Red.), Estetiska lärprocesser: upplevelser, praktiker och kunskapsformer (s. 9-14). Studentlitteratur AB.

Løvlie, L. (1990). Den estetiske erfaring. Nordisk pedagogik 10, 1-18.

Løvlie, L. (2013). Verktøyskolen. Norsk pedagogisk tidsskrift, 3, 185-199. https://doi.org/ https://doi.org/10.18261/ISSN1504-2987-2013-03-03

Maguire, M. \& Delahunt, B. (2017). Doing a Thematic Analysis: A Practical, Step-by-Step Guide for Learning and Teaching Scholars. All Ireland Journal of Higher Education, 9, 3351-33514. http://ojs.aishe.org/index.php/aishe-j/article/view/335

Malmanger, M. (2000). Kunsten og det skjønne. Vesterlandsk estetikk og kunstteori fra Homer til Hegel. Aschehoug \& Co. 
Meld. St. 22 (2010-2011). Motivasjon - mestring - muligheter. Kunnskapsdepartementet. https://www.regjeringen.no/contentassets/0b74cdf7fb4243a39e249bce0742cb95/no/pdfs/s tm201020110022000dddpdfs.pdf

Meld. St. 28 (2015-2016). Fag - Fordypning - Forståelse — En fornyelse av Kunnskapsløftet. Kunnskapsdepartementet. https://www.regjeringen.no/no/dokumenter/meld.-st.-28-20152016/id2483955/

Merriam, S., B. (1998). Qualitative Research and Case Study Applications in Education. Jossey-Bass Inc., Publishers.

NESH. (2016). Den nasjonale forskningsetiske komité for samfunnsfag og humaniora. De nasjonale forskningsetiske komitéene.

https://www.forskningsetikk.no/globalassets/dokumenter/4-publikasjoner-sompdf/forskningsetiske-retningslinjer-for-samfunnsvitenskap-humaniora-juss-og-teologi.pdf

Nordberg-Schulz, C. (1997). Øye og hånd. Essays og artikler. Ny rekke. Gyldendal.

NOU 2015:8. (2015). Fremtidens skole: fornyelse av fag og kompetanser.

Kunnskapsdepartementet.

https://www.regjeringen.no/contentassets/da148fec8c4a4ab88daa8b677a700292/no/pdfs/ nou201520150008000dddpdfs.pdf

Næss, A. (1976). Økologi, samfunn og livsstil. Utkast til en økosofi. Universitetsforlaget.

Næss, A. (1999). Livsfilosofi. Et personlig bidrag om følelser og fornuft. Universitetsforlaget.

Pestalozzi, J. H. (1894). How Gertrude Teaches her Children: An Attempt to Help Mothers to Teach their own Children and an Account of the Method. Swan Sonnenschein \& Co.

Postholm, M. B. (2010). Kvalitativ metode. En innføring med fokus på fenomenologi, etnografi og kasusstudier. Universitetsforlaget.

Prøitz, T. S. \& Nordin, A. (2019). Learning Outcomes in Scandinavian Education through the Lens of Elliot Eisner. Scandinavian Journal of Educational Research, 64(5), 645-660. https://doi.org/https://search.datacite.org/works/10.1080/00313831.2019.1595717

Smestad, B. (2014). Hvilke fag får GLU-studentene kompetanse i? En analyse av grunnskolelcererstudentenes studiepoengproduksjon 2012/13. Høgskolen i Oslo og Akershus.

Stevenson, L. M. \& Deasy, R. J. (2005). Third space: when learning matters. Arts Education Partnership.

Sæbø, A. B. (2009). Drama og elevaktiv laring : en studie av hvordan drama svarer på undervisnings- og leringsprosessens didaktiske utfordringer [Doktorgradsavhandling]. Norges teknisk-naturvitenskapelige universitet.

Sæbø, A. B. (2010). Drama og elevenes engasjerte medvirkning i læreprosessen. I B. Aamotsbakken (Red.), Læring og medvirkning. Universitetsforlaget.

Telhaug, A. O. (2004). Kunnskapsløftet - ny eller gammel skole? En beskrivelse og analyse av Clemets reformer i grunnoppleringen. Cappelen Akademisk Forlag.

Tjora, A. H. (2017). Kvalitative forskningsmetoder i praksis (3. utg. utg.). Gyldendal akademisk.

Ulvik, M. (2020). Promoting Aesthetical Values to Education. Frontiers in Education, 5, 1-8. https://doi.org/https://doi.org/10.3389/feduc.2020.00034

Utdanningsdirektoratet. (2020). Fysisk aktivitet og estetiske uttrykksformer i skolen. https://www.udir.no/laring-og-trivsel/tilpasset-opplaring/fysisk-aktivitet-og-estetiskeuttrykksformer/

Utdanningsdirektoratet. (2021). Tall om elever, skoler, spesialundervisning og særskilt norsk. https://www.udir.no/tall-og-forskning/statistikk/statistikk-grunnskole/tall-om-elever-og$\underline{\text { skoler/ }}$ 
Willbergh, I. (2008). Mimesis, didaktikk og digitale laremidler [Norges teknisknaturvitenskapelige universitet, Fakultet for samfunnsvitenskap og teknologiledelse, Pedagogisk institutt]. Trondheim.

Willbergh, I. (2019). "Som-om"-opplevelser - viktig for demokratiet. I K. H. Karlsen \& G. B. Bjørnstad (Red.), Skaperglede, engasjement og utforskertrang. Nye perspektiver på estetiske og tverrfaglige undervisningsmetoder som redskap i pedagogisk virksomhet (s. 225-239). Universitetsforlaget.

Østern, A. L. (2010). Estetisk tilnærming til læring. I S. S. Hovdenak \& O. Erstad (Red.), Kunnskap i skolen (s. 181-198). Tapir Akademisk Forlag.

Østern, T. P., Selander, S. \& Østern, A. L. (2019). Dybde//undervisning - sanselige designteoretiske og dramaturgiske perspektiver. I T. P. Østern, T. Dahl, A. Strømme, J. A. Petersen, A. L. Østern, \& S. Selander (Red.), Dybde/laring - en flerfaglig, relasjonell og skapende tilncerming (s. 57-77). Universitetsforlaget. 